\title{
A Diastereoselective Synthetic Approach towards the Synthesis of Berkeleylactone $F$ and Its 4-epi-Derivative
}

\author{
Srijana Subba ${ }^{a}$ \\ Sumit Saha*a (i) \\ Susanta Mandal \\ ${ }^{a}$ Department of Chemistry, National Institute of Technology \\ Sikkim, Ravangla, South Sikkim 737139, India \\ sumit.che@nitsikkim.ac.in \\ ${ }^{b}$ Department of Chemistry, Sikkim University, Tadong, Gangtok, \\ Sikkim737102, India
}

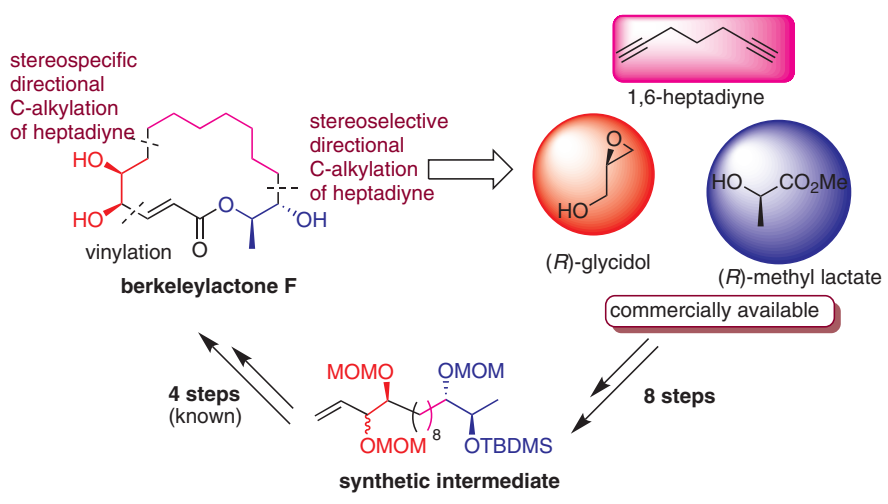

pergillus sp. SCSGAF $0076^{4 a}$ and from the co-culture fermentation of two fungal species Penicillium fuscum and Penicillium camembertii/clavigerum, ${ }^{\text {5a }}$ respectively. Berkeleylactone $\mathrm{F}$ showed moderate inhibitory activity against CCRF-CEM leukemia cells. Several efforts by synthetic organic chemists for the synthesis of $A 26771 \mathrm{~B}^{3 \mathrm{~b}-\mathrm{e}}$ and aspergillide $\mathrm{D}^{4 \mathrm{~b}-\mathrm{d}}$ have been reported. However, there have been fewer attempts towards the synthesis of the recently disclosed berkeleylactone derivatives, even though they possess promising antimicrobial activities with attractive stereochemical and functional diversity. Syntheses of berkeleylactone $A$ and berkeleylactone $F$ have been reported recently. ${ }^{5 \mathrm{~b}, \mathrm{c}}$ Berkeleylactone $\mathrm{C}, \mathrm{E}$, and $\mathrm{H}$ also show impressive biological activity (Figure 1 ). ${ }^{5 a}$

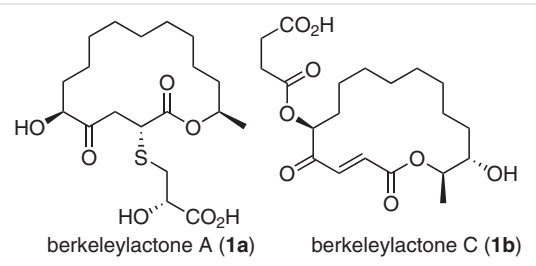<smiles>CC(CCCCCCCCC(OC(=O)CCC(=O)O)C(O)/C=C/C(=O)O)OC(=O)O</smiles><smiles>CC(O)C(O)CCCCCCCCC(O)C(O)/C=C/C(=O)O</smiles>

berkeleylactone $\mathrm{E}(\mathbf{1 c})$ berkeleylactone $\mathrm{F}$ (1d) ganic chemists due to their wide scope of applications.

There are several 16-membered macrolactones with promising biological activities. ${ }^{2}$ However, the well-known

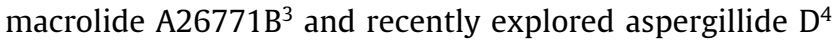
and berkeleylactone $\mathrm{A}-\mathrm{H}^{5}$ are some of the simple 16 -membered macrolides that also exhibit impressive antibacterial activity. Aspergillide D and berkeleylactones A-H were isolated from the culture broth of a marine-derived fungus As- 
We selected berkeleylactone $\mathrm{F}$ as the target molecule to explore ways to improve the methodology in our initiative for the general synthesis of 16-membered macrolides. Our main focus was to develop a generalized synthetic strategy for the synthesis of macrolides, involving fewer synthetic steps starting from commercially available materials.

The retrosynthetic strategy for Berkeleylactone $F$ is shown in Scheme 1. Cyclization leading to compound 1d can be achieved by ring-closing metathesis (RCM) of compound 2.

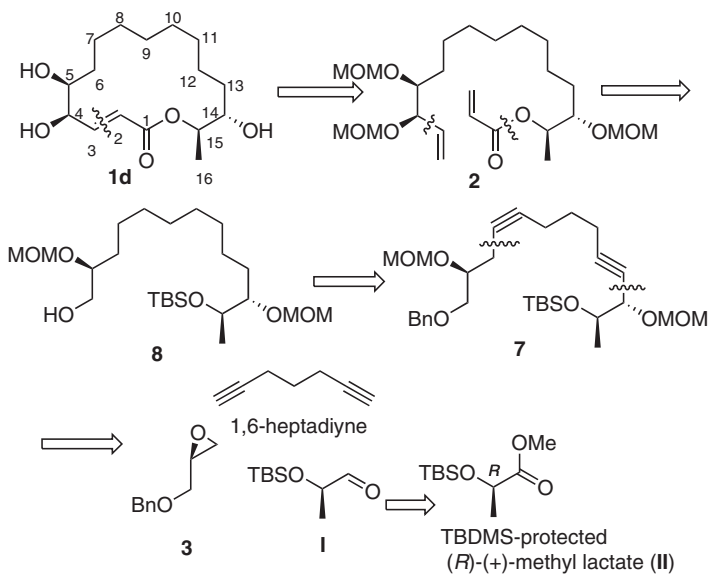

Scheme 1 The retrosynthetic strategy for Berkeleylactone F

The precursor, compound $\mathbf{2}$ for RCM can be obtained by the oxidation of alcohol $\mathbf{8}$, followed by vinylation and chloromethyl methyl etherification (MOM). Silyl group deprotection followed by acrylation of the secondary hydroxyl group are necessary to reach compound $\mathbf{2}$ starting from compound $\mathbf{8}$. Removal of the benzyl group and reduction of the alkynes of compound $\mathbf{7}$ in the same step will lead to compound 8. Further disconnections lead to the starting materials, protected $(R)$-glycidol 3, protected $(R)$ (+)-methyl lactate (II) and 1,6-heptadiyne (Scheme 1).

A long aliphatic chain together with a hydroxyl functionality are major parts of any macrolactone ring. The use of long-chain terminal diols $\mathrm{s}^{3 \mathrm{e}, 4 \mathrm{c}, 4 \mathrm{~d}, 6 \mathrm{a}-\mathrm{c}}$ or terminal alkynes followed by a zipper reaction ${ }^{6 \mathrm{~d}-\mathrm{e}}$ are the most commonly used strategies to generate the macrolactone. However, these strategies can be quite lengthy. Herein, we report the use of 1,6-heptadiyne to construct the aliphatic chain of the macrolactone. Two-directional C-alkylation of 1,6-heptadiyne with an epoxide and aldehyde, respectively, will introduce the hydroxyl functionalities to the macrolactone ring. There are reports of such applications of diynes in the total synthesis of natural products but they have not previously been applied in the synthesis of macrolactones. ${ }^{7}$

We initiated our synthesis with commercially available 1,6-heptadiyne and $(R)$-glycidol. The free hydroxyl group of $(R)$-glycidol was benzylated using benzyl bromide in the presence of sodium hydride in $\mathrm{N}, \mathrm{N}$-dimethylformamide as solvent to produce benzylated $(R)$-glycidol 3. ${ }^{8 a} 1,6$-Heptadiyne was treated with $n$-BuLi followed by $\mathrm{BF}_{3} \cdot \mathrm{OEt}_{2}$ and subsequently reacted with benzylated glycidol 3 at $-78{ }^{\circ} \mathrm{C}$ to furnish compound $4 .^{8 \mathrm{~b}}$ It was interesting to observe that epoxide ring opening of $\mathbf{3}$ takes place regioselectively to afford desired compound $\mathbf{4}$ in good yield after two hours. However, the disubstituted by-product was also generated in small amounts after running the reaction for extended periods. This minor by-product could be readily separated by column chromatography from the desired product 4. Compound 4 was converted into MOM ether $\mathbf{5}$ using chloromethyl methyl ether in the presence of $\mathrm{N}, \mathrm{N}$-diisopropylethylamine in $\mathrm{CH}_{2} \mathrm{Cl}_{2} \cdot{ }^{6 \mathrm{~b}}$ Compound 5 was treated with $n$ BuLi at $-78{ }^{\circ} \mathrm{C}$ to generate the corresponding alkynyl lithium derivative, which was allowed to react in situ with $(R)$ 2-(tert-butyldimethylsilyloxy)propanal $(\mathrm{I})^{8 \mathrm{c}, \mathrm{d}}$ (derived from commercially available $(R)-(+)$-methyl lactate using DIBAL$\mathrm{H}$ in anhydrous hexane at $-78{ }^{\circ} \mathrm{C}$ ) at the same temperature to produce the Felkin model controlled product in $80 \%$ yield, producing the anti-isomer $\mathbf{6}$ exclusively. The observed high diastereoselectivity is in complete agreement with the report of Léséleuc et al..$^{9 a}$ Other reports ${ }^{9 b-f}$ for the nucleophilic addition of alkynyllithium to optically active aldehydes derived from lactate also strongly support the proposed outcome (Scheme 2).

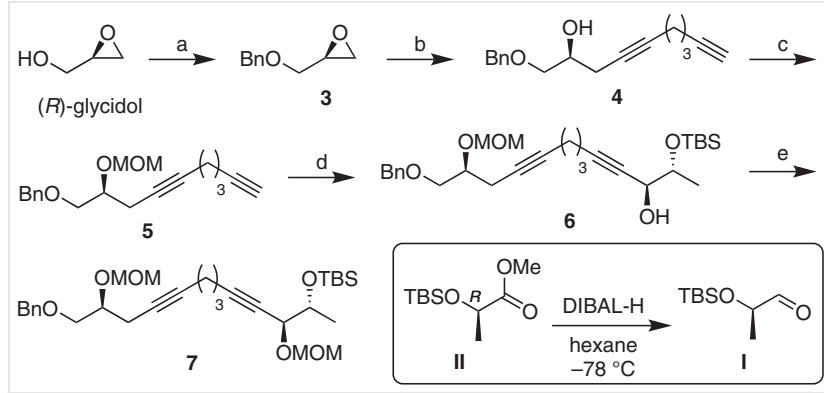

Scheme 2 Reagents and conditions: (a) $\mathrm{BnBr}, \mathrm{NaH}, \mathrm{DMF}, 0^{\circ} \mathrm{C}$ to rt, $8 \mathrm{~h}$, 90\%; (b) n-BuLi, 1,6-heptadiyne, $\mathrm{BF}_{3} \cdot \mathrm{OEt}_{2}$, THF, $-78^{\circ} \mathrm{C}, 2 \mathrm{~h}, 75 \%$; (c) MOMCl, DIPEA, $\mathrm{CH}_{2} \mathrm{Cl}_{2}, 0^{\circ} \mathrm{C}$ to rt, $5 \mathrm{~h}, 90 \%$; (d) $n$-BuLi, I, $-78^{\circ} \mathrm{C}, 2 \mathrm{~h}$, $80 \%$; (e) MOMCl, DIPEA, $\mathrm{CH}_{2} \mathrm{Cl}_{2}, 0{ }^{\circ} \mathrm{C}$ to rt, $5 \mathrm{~h}, 85 \%$.

The highly diastereoselective preference for the antiproduct may be explained by the non-chelating Felkin-Anh model, as shown in Figure 2. In accordance with the model, the electron-withdrawing group as well as the sterically hindered bulky OTBS group are preferentially placed antito the carbonyl group in the presence of non-chelating cations such as $\mathrm{Li}^{+}$. The oxygen atom of the OTBS group at the $\alpha$-position of the aldehyde is unable to chelate with the carbonyl oxygen in the presence of the poor chelating cation $\mathrm{Li}^{+}$. Nucleophilic attack takes place from the side of smallest group $(\mathrm{H})$. As a result, the OTBS group at the $\alpha$-position to the aldehyde induces the anti stereochemistry (Figure 2). ${ }^{10}$ 


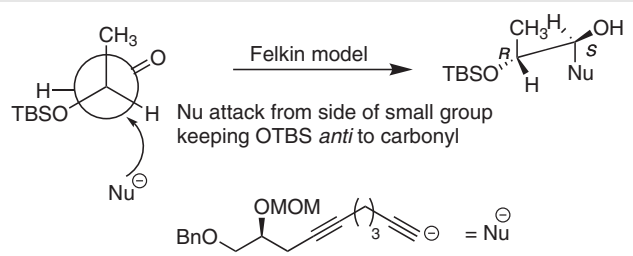

Figure 2 The non-chelating Felkin-Anh model

The free hydroxyl group of compound 6 was transformed into the corresponding MOM ether using chloromethyl methyl ether in the presence of $\mathrm{N}, \mathrm{N}$-diisopropylethylamine in $\mathrm{CH}_{2} \mathrm{Cl}_{2}$ to produce compound $\mathbf{7}$ (Scheme 2).

One-pot reduction of the $\mathrm{C}-\mathrm{C}$ triple bonds and deprotection of the benzyl group of $\mathbf{7}$ was achieved by hydrogenation over $\mathrm{Pd} / \mathrm{C}$ in methanol, ${ }^{11}$ which afforded $\mathbf{8}$ in good yield. The primary hydroxyl group of the latter was oxidized using pyridinium chlorochromate in the presence of 4 Å molecular sieves at room temperature. The crude aldehyde obtained after work up was directly subjected to chelation-controlled vinylation using vinyl magnesium bromide in THF at $-78^{\circ} \mathrm{C}$ to produce an inseparable mixture of 9 (syn-9a/anti-9b $=5: 1$, determined by ${ }^{1} \mathrm{H}$ NMR analysis; Scheme 3). The diastereoselectivity of the syn-isomer over the anti-isomer is in good agreement with literature precedent. ${ }^{12}$ The syn-selectivity may be explained by considering Cram's chelate model as shown in Figure 3.

In accordance with the Cram chelate model, the MOM group is placed syn- to carbonyl group in the presence of the chelating $\mathrm{Mg}^{+2}$. Nucleophilic attack at the carbonyl group in the chelated substrate takes place from the side of the smallest group (Figure 3). The syn-selectivity is consistent with previous reports for vinylation of aldehydes with an $\alpha$-MOM group. ${ }^{10,12 c, d, h}$

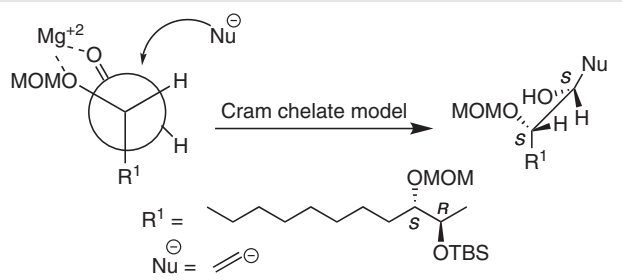

Figure 3 Cram chelate model

Compound 9 was treated with methoxymethyl chloride in the presence of $\mathrm{N}, \mathrm{N}$-diisopropylethylamine to produce compound 10 in a 5:1 syn/anti ratio (Scheme 3). We were unable to separate this diastereomeric mixture at this stage. Recently Reddy et al. completed the total synthesis of berkeleylactone F $\mathbf{1 d}$ via the minor isomer 10b obtained in our strategy (Scheme 4)..$^{5 \mathrm{c}}$ Reddy et al. used asymmetric epoxidation as a key step to introduce the asymmetric centre.
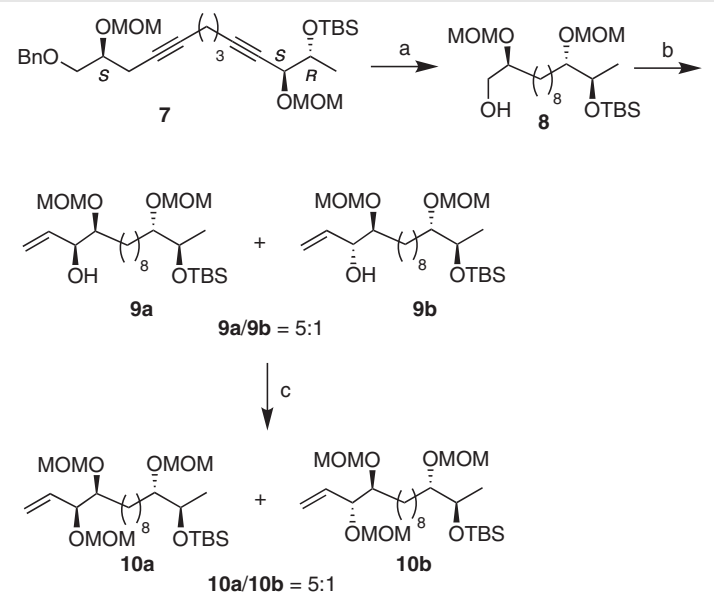

Scheme 3 Reagents and conditions: (a) $\mathrm{H}_{2}, \mathrm{Pd} / \mathrm{C}, \mathrm{MeOH}$, r.t., $1.5 \mathrm{~h}, 65 \%$; (b) i. PCC, Mol Sieve, $\mathrm{CH}_{2} \mathrm{Cl}_{2}$, r.t., 3 h; (ii) Vinyl $\mathrm{MgBr}$, THF, $-78{ }^{\circ} \mathrm{C}, 55 \%$ (over two steps); (c) MOMCl, DIPEA, $\mathrm{CH}_{2} \mathrm{Cl}_{2}, 0{ }^{\circ} \mathrm{C}$ to r.t., $5 \mathrm{~h}, 85 \%$.

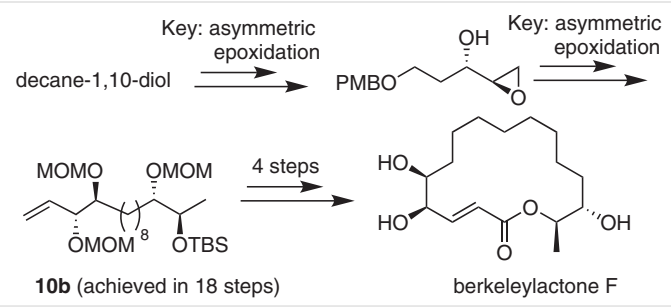

Scheme 4 Synthesis of berkeleylactone F 1d via the minor isomer 10b

Thus, the present synthesis of compounds $10 \mathbf{a}$ and $\mathbf{1 0 b}$, which was achieved in eight steps in $12 \%$ yield, leads to the formal synthesis of 4-epi-berkeleylactone $\mathrm{F}$ and berkeleylactone F, respectively (Scheme 5).

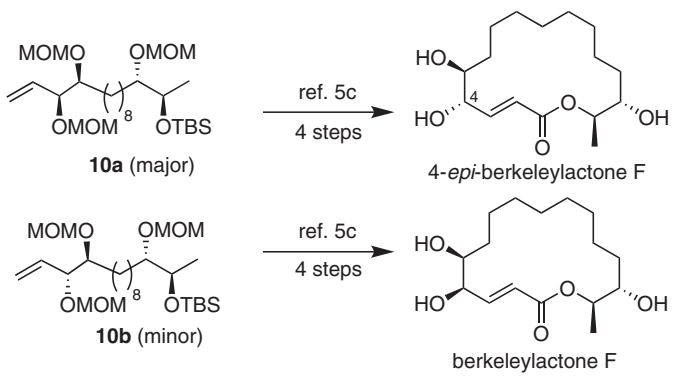

Scheme 5 Formal synthesis of 4-epi-berkeleylactone F and berkeleylactone $\mathrm{F}$

In summary, we present a synthesis of berekeleylactone $\mathrm{F}$ and its C-4 epi-isomer starting from commercially available 1,6-heptadiyne and optically active $(R)$-glycidol. ${ }^{13,14}$ The important feature of the synthesis is the application of 1,6-heptadiyne in directed C-alkylation functionalization at both ends of the diyne; which is the first time such an approach has been used in 16-membered macrolactone syn- 
thesis. In addition, our strategy involves fewer steps toward the synthesis of berkeleylactone $\mathrm{F}$ and its 4-epi-derivative than previous approaches.

\section{Funding Information}

The Department of Science and Technology, Ministry of Science and Technology, India (INSPIRE Faculty Award- IFA 12-CH 45) is gratefully acknowledged for financial support.

\section{Acknowledgment}

The authors acknowledge NIT Sikkim \& TEQIP III for infrastructure support and Dr. Sajal Das, NBU and Tapan Kumar Kuilya, Sandip Guchhait, Joyanta Mondal, Soumik Bardhan, Susanta Mandal for constant support.

\section{Supporting Information}

Supporting information for this article is available online at https://doi.org/10.1055/s-0040-1707305.

\section{References and Notes}

(1) (a) Laslop, N. V.; Mankin, A. S. Trends Biochem. Sci. 2018, 43, 668. (b) Kanoh, S.; Rubin, B. K. Clin. Microbiol. Rev. 2010, 23, 590. (c) Przybylski, P. Curr. Org. Chem. 2011, 15, 328. (d) Gaynor, M.; Mankin, A. S. Curr. Top. Med. Chem. 2003, 3, 949.

(2) (a) Feng, Y.; Yu, Z.; Zhang, S.; Xue, Z.; Huang, J.; Zhang, H.; Wan, X.; Chen, A.; Wang, J. J. Agric. Food Chem. 2019, 67, 4782. (b) Arsic, B.; Barber, J.; Čikoš, A.; Mladenovic, M.; Stankovic, N.; Novak, P. Int. J. Antimicrob. Agents 2018, 51, 283. (c) Cheng, H.; Huang, H.; Huang, G. Eur. J. Med. Chem. 2018, 157, 925. (d) Gao, H.; Huang, G. Bioorg. Med. Chem. 2018, 26, 5578. (e) Hajare, A. K.; Ravikumar, V.; Khaleel, S.; Bhuniya, D.; Reddy, D. S. J. Org. Chem. 2011, 76, 963. (f) Sugamata, R.; Sugawara, A.; Nagao, T.; Suzuki, K.; Hirose, T.; Yamamoto, K.; Oshima, M.; Kobayashi, K.; Sunazuka, T.; Akagawa, K. S.; Omura, S.; Nakayama, T.; Suzuki, K. J. Antibiot. 2014, 67, 213. (g) Pan, J. J.; Wana, X.; Zhang, S. Y.; Huang, J.; Zhang, H.; Chen, A. L.; Wang, J. D. Bioorg. Med. Chem. Lett. 2016, 26, 3376. (h) Yadav, J. S.; Das, S. K.; Sabitha, G. J. Org. Chem. 2012, 77, 11109.

(3) (a) Michel, K. H.; Demoarco, P. V.; Nagarajan, R. J. Antibiot. 1977, 30, 571. (b) Chatterjee, S.; Subramanian, M.; Sharma, A.; Chattopadhyay, S. Nat. Prod. Commun. 2018, 13, 1535. (c) Chatterjee, S.; Sharma, A.; Chattopadhyay, S. RSC Adv. 2014, 4, 42697. (d) Reddy, R.; Suman, D.; Rao, N. N. Synlett 2012, 23, 272. (e) Saidhareddya, P.; Shaw, A. K. RSC Adv. 2015, 5, 29114.

(4) (a) Baoa, J.; Xua, X. Y.; Zhanga, X. Y.; Qi, S. H. Nat. Prod. Commun. 2013, 8, 1127. (b) Talakokkula, A.; Baikadi, K.; Narsaiah, A. V. ARKIVOC 2019, 307. (c) Jena, B. K.; Reddy, G. S.; Mohapatra, D. K. Org. Biomol. Chem. 2017, 15, 1863. (d) Kandimalla, S. R.; Reddy, B. V. S.; Sabitha, G. Synth. Commun. 2019, 49, 3191.

(5) (a) Stierle, A. A.; Stierle, D. B.; Decato, D.; Priestley, N. D.; Alverson, J. B.; Hoody, J.; McGrath, K.; Klepacki, D. J. Nat. Prod. 2017, 80, 1150. (b) Ferko, B.; Zeman, M.; Formica, M.; Veselý, S.; Doháňošová, J.; Moncol, J.; Olejníková, P.; Berkeš, D.; Jakubec, P.;
Dixon, D. J.; Caletková, O.J. Org. Chem. 2019, 84, 7159. (c) Reddy, M. S.; Manikanta, G.; Krishna, P. R. Tetrahedron Lett. 2019, 60, 504.

(6) (a) Sudina, P. R.; Motati, D. R.; Seema, A. J. Nat. Prod. 2018, 81, 1399. (b) Krishna, P. R.; Prabhakar, S.; Ramana, D. V. Tetrahedron Lett. 2012, 53, 6843. (c) Venkatraman, L.; Aldrich, C. C.; Sherman, D. H.; Fecik, R. A. J. Org. Chem. 2005, 70, 7267. (d) Reddy, C. R.; Suman, D.; Rao, N. N. Eur. J. Org. Chem. 2013, 3786. (e) Avocetien, K. F.; Li, J. J.; Liu, X.; Wang, Y.; Xing, Y.; O’Doherty, G. A. Org. Lett. 2016, 18, 4970.

(7) (a) Jiang, S.; Liu, Z. H.; Sheng, G.; Zeng, B. B.; Cheng, X. G.; Wu, Y. L.; Yao, Z. J. J. Org. Chem. 2002, 67, 3404. (b) Liau, B. B.; Gnanadesikan, V.; Corey, E. J. Org. Lett. 2008, 10, 1055. (c) Maezaki, N.; Tominaga, H.; Kojima, N.; Yanai, M.; Urabe, D.; Tanaka, T. Chem. Commun. 2004, 406. (d) Maezaki, N.; Tominaga, H.; Kojima, N.; Yanai, M.; Urabe, D.; Ueki, R.; Tanaka, T.; Yamori, T. Chem. Eur. J. 2005, 11, 6237. (e) Falck, J. R.; Wallukat, G.; Puli, N.; Goli, M.; Arnold, C.; Konkel, A.; Rothe, M.; Fischer, R.; Müller, D. N.; Schunck, W. H. J. Med. Chem. 2011, 54, 4109. (f) Liu, H. X.; Huang, G. R.; Zhang, H. M.; Jiang, S.; Wu, J. R.; Yao, Z. J. ChemBioChem 2007, 8, 172. (g) Jiang, S.; Li, Y.; Chen, X. G.; Hu, T. S. Wu Y. L.; Yao, Z. J. Angew. Chem. Int. Ed. 2004, 43, 329. (h) Zhao, H.; Gorman, J. S. T.; Pagenkopf, B. L. Org. Lett. 2006, 8, 4379 .

(8) (a) González-Gil, I.; Zian, D.; Vázquez-Villa, H.; HernándezTorres, G.; Martínez, R. F.; Khiar-Fernández, N.; Rivera, R.; Kihara, Y.; Devesa, I.; Mathivanan, S.; Rosell del Valle, C.; Zambrana-Infantes, E.; Puigdomenech, M.; Cincilla, G.; SanchezMartinez, M.; Rodríguez de Fonseca, F.; Ferrer-Montiel, A. V.; Chun, J.; López-Vales, R.; López-Rodríguez, M. L.; Ortega-Gutiérrez, S. J. Med. Chem. 2020, 63, 2372. (b) Iio, K.; Sachimori, S.; Watanabe, T.; Fuwa, H. Org. Lett. 2018, 20, 7851. (c) Shiina, I.; Takasuna, Y.; Suzuki, R.; Oshiumi, H.; Komiyama, Y.; Hitomi, S.; Fukui, H. Org. Lett. 2006, 8, 5279. (d) Ramulu, U.; Ramesh, D.; Rajaram, S.; Reddy, S. P.; Venkatesham, K.; Venkateswarlu, Y. Tetrahedron: Asymmetry 2012, 23, 117.

(9) (a) Léséleuc, M.; Godin, E.; Parisien-Collette, S.; Lévesque, A.; Collins, S. K. J. Org. Chem. 2016, 81, 6750. (b) Shin, D.; Yang, J. E.; Lee, S. B.; Nho, C. W. Bioorg. Med. Chem. Lett. 2010, 20, 7549. (c) Peňaška, T.; Koukal, P.; Kotora, M. Eur. J. Org. Chem. 2018, 147. (d) Reddy, K. S. N.; Reddy, A. Y.; Sabitha, G. Synthesis 2016, 48, 3812. (e) Trost, B. M.; Sieber, J. D.; Qian, W.; Dhawan, R.; Ball, Z. T. Angew. Chem. Int. Ed. 2009, 48, 5478. (f) Wu, J.; Wu, Y.; Jian, Y.; Zhang, Y. Chin. J. Chem. 2009, 27, 13.

(10) (a) Mengel, A.; Reiser, O. Chem. Rev. 1999, 99, 1191. (b) Guillarme, S.; Plé, K.; Banchet, A.; Liard, A.; Haudrechy, A. Chem. Rev. 2006, 106, 2355.

(11) (a) Beemelmanns, C.; Woznica, A.; Alegado, R. A.; Cantley, A. M.; King, N.; Clardy, J. J. Am. Chem. Soc. 2014, 136, 10210. (b) Porta, A.; Chiesa, F.; Quaroni, M.; Persico, M.; Moratti, R.; Zanoni, G.; Vidari, G. Eur. J. Org. Chem. 2014, 2111.

(12) (a) Sabitha, G.; Reddy, C. N.; Gopal, P.; Yadav, J. S. Tetrahedron Lett. 2010, 51, 5736. (b) Raghavan, S.; Yelleni, M. K. R. Tetrahedron 2017, 73, 4371. (c) Rao, J. P.; Rao, B. V. Tetrahedron: Asymmetry 2010, 21, 930. (d) Kumar, P.; Naidu, S. V. J. Org. Chem. 2006, 71, 3935. (e) Roush, W. R.; Bennett, C. E.; Roberts, S. E. J. Org. Chem. 2001, 66, 6389. (f) Allu, S. R.; Banne, S.; Jiang, J.; Qi, N.; Guo, J.; He, Y. J. Org. Chem. 2019, 84, 7227. (g) Kim, D.; Lee, J.; Shim, P. J.; Lim, J. I.; Jo, H.; Kim, S. J. Org. Chem. 2002, 67, 764. (h) Reetz, M. T. Angew. Chem., Int. Ed. Engl. 1984, 23, 556.

(13) Synthesis of (S)-1-(Benzyloxy)deca-4,9-diyn-2-ol (4): To a solution of 1,6-heptadiyne $(0.5 \mathrm{~mL}, 4.57 \mathrm{mmol}, 1.0$ equiv) in anhydrous THF $(10 \mathrm{~mL})$ at $-78{ }^{\circ} \mathrm{C}$ under argon was added $n$-BuLi 
(4.6 mL, $4.6 \mathrm{mmol}, 1.0 \mathrm{M}$ in hexane 1 equiv). The resulting mixture was stirred for $30 \mathrm{~min}$ at this temperature and a solution of epoxide 3 ( $250 \mathrm{mg}, 1.52 \mathrm{mmol}, 0.33$ equiv, dissolved in anhydrous THF, $5 \mathrm{~mL}$ ) was added dropwise, followed by rapid addition of $\mathrm{BF}_{3} \cdot \mathrm{Et}_{2} \mathrm{O}$ (freshly distilled, $0.6 \mathrm{~mL}, 6.66 \mathrm{mmol}, 1.45$ equiv) The reaction mixture was stirred for $1.5 \mathrm{~h}$ and then quenched with saturated aqueous $\mathrm{NH}_{4} \mathrm{Cl}$ solution and extracted with $\mathrm{Et}_{2} \mathrm{O}(3 \times 20 \mathrm{~mL})$. The combined organic extracts were washed with water and brine, dried over anhydrous $\mathrm{Na}_{2} \mathrm{SO}_{4}$ and concentrated under vacuum. The crude material was purified by column chromatography on silica gel (10\% EtOAc in pet ether (PE)) to give pure alcohol $4(0.88 \mathrm{~g}, 3.43 \mathrm{mmol} 75 \%)$ as a yellow oily liquid. TLC: $R_{f} 0.76$ (10\% EtOAc in PE). IR: $1096,1428,1633$, $2115,2946,3453 \mathrm{~cm}^{-1} .{ }^{1} \mathrm{H}$ NMR $\left(400 \mathrm{MHz}, \mathrm{CDCl}_{3}\right): \delta=1.71(\mathrm{p}$, $J=7.0 \mathrm{~Hz}, 2 \mathrm{H}), 1.99(\mathrm{t}, J=2.6 \mathrm{~Hz}, 1 \mathrm{H}), 2.28-2.33(\mathrm{~m}, 4 \mathrm{H}), 2.42-$ $2.46(\mathrm{~m}, 2 \mathrm{H}), 3.52\left(\mathrm{dd}, J_{1,2}=3.92 \mathrm{~Hz}, J_{1,3}=9.52 \mathrm{~Hz}, 1 \mathrm{H}\right), 3.61$ $\left(\mathrm{dd}, J_{1,2}=6.68 \mathrm{~Hz}, J_{1,3}=9.52 \mathrm{~Hz}, 1 \mathrm{H}\right), 3.92-3.98(\mathrm{~m}, 1 \mathrm{H}), 4.59(\mathrm{~s}$, $2 \mathrm{H}), 7.30-7.40(\mathrm{~m}, 5 \mathrm{H}) .{ }^{13} \mathrm{C}$ NMR $\left(100 \mathrm{MHz}, \mathrm{CDCl}_{3}\right): \delta=17.5$, 17.8, 23.9, 27.7, 68.8, 69.2, 72.9, 73.4, 76.4, 81.4, 83.5, 127.8, 128.3, 137.9. HRMS: $\mathrm{m} / z[\mathrm{M}+\mathrm{Na}]^{+}$calcd for $\mathrm{C}_{17} \mathrm{H}_{20} \mathrm{O}_{2} \mathrm{Na}$ : 279.1361; found: 279.1361 .

(14) Synthesis of $(5 S, 14 S, 15 R)-5-((B e n z y l o x y)$ methyl)-15,17,18,18pentamethyl-2,4,16-trioxa-17-silanonadeca-7,12-diyn-14-ol (6): $(R)-(+)-M e t h y l$ lactate $(1.0 \mathrm{~g}, 9.60 \mathrm{mmol}, 1$ equiv), was dissolved in anhydrous DMF (5 mL), and imidazole (1.06 g, 15.57 mmol, 1.6 equiv) was added. The solution was cooled in an ice bath and TBSCl ( $1.45 \mathrm{~g}, 9.60 \mathrm{mmol}, 1$ equiv) was added slowly in portions. After the completion of addition, the ice bath was allowed to melt gradually overnight. After $18 \mathrm{~h}$, the reaction mixture was diluted with water $(3 \mathrm{~mL})$ and hexanes $(10 \mathrm{~mL})$. The aqueous phase was separated and extracted with hexanes $(60 \mathrm{~mL})$, and the combined organic extract was washed with brine, dried over anhydrous $\mathrm{Na}_{2} \mathrm{SO}_{4}$, filtered, and concentrated by rotary evaporation to afford the TBS ether $(1.6 \mathrm{~g}, 7.33 \mathrm{mmol}$, $76 \%)$ as a colorless liquid, which was used without purification. The above prepared TBS protected $(R)-(+)$-methyl lactate $(1.00 \mathrm{~g}$,
$4.58 \mathrm{mmol}, 1$ equiv), in hexanes $(20 \mathrm{~mL})$, was cooled to $-78{ }^{\circ} \mathrm{C}$, DIBAL-H (4.7 mL, $1.0 \mathrm{M}$ in hexanes, $4.7 \mathrm{mmol}, 1.0$ equiv) was added dropwise and the mixture was stirred for 45 minutes at $-78{ }^{\circ} \mathrm{C}$. The reaction mixture was then quenched by addition of $\mathrm{MeOH}(1.0 \mathrm{~mL})$ and stirred for $15 \mathrm{~min}$ at $-78{ }^{\circ} \mathrm{C}$. The cold solution was transferred to a round-bottom flask containing saturated aqueous Rochelle salt $(10 \mathrm{~mL})$ and the resulting mixture was vigorously stirred for $30 \mathrm{~min}$. The aqueous phase was separated and extracted with hexanes, and the combined organic extracts were washed with brine, dried over anhydrous $\mathrm{Na}_{2} \mathrm{SO}_{4}$, filtered, and concentrated to afford the aldehyde $(0.70 \mathrm{~g}$, $3.66 \mathrm{mmol}, 80 \%$ ) as a colorless liquid.

To a solution of compound $\mathbf{5}$ ( $0.90 \mathrm{~g}, 3.0 \mathrm{mmol}, 1$ equiv) in anhydrous THF ( $15 \mathrm{~mL}), n$-BuLi $(.3 .0 \mathrm{~mL}, 3.0 \mathrm{mmol}, 1 \mathrm{M}$ in THF, 1 equiv) was added dropwise at $-78{ }^{\circ} \mathrm{C}$. The solution was stirred for $30 \mathrm{~min}$ at the same temperature and then freshly prepared aldehyde was added to the reaction mixture dropwise $(0.70 \mathrm{~g}$, $3.66 \mathrm{mmol}, 1.2$ equiv over $30 \mathrm{mins}$ ) and the mixture was stirred for $2.5 \mathrm{~h}$. The reaction mixture was quenched with saturated aqueous $\mathrm{NH}_{4} \mathrm{Cl}$ and the organic phase was separated and evaporated under reduced pressure. The aqueous layer was extracted with EtOAc and the organic extract was washed with brine, dried over anhydrous $\mathrm{Na}_{2} \mathrm{SO}_{4}$, filtered and concentrated by rotary evaporation. Column chromatographic purification $(10 \%$ EtOAc in PE) of the resultant crude residue provided pure alcohol 6 (1.20 g, $2.45 \mathrm{mmol}, 80 \%)$ as a pale-yellow liquid. TLC: $R_{f} 0.67$ (5\% EtOAc in PE). IR: 1252, 1494, 1628, 2245, 2985, 3470 $\mathrm{cm}^{-1} .{ }^{1} \mathrm{H}$ NMR $\left(400 \mathrm{MHz}, \mathrm{CDCl}_{3}\right): \delta=0.11(\mathrm{~s}, 3 \mathrm{H}), 0.12(\mathrm{~s}, 3 \mathrm{H})$, $0.92(\mathrm{~s}, 9 \mathrm{H}), 1.24(\mathrm{~d}, J=6.24 \mathrm{~Hz}, 3 \mathrm{H}), 1.59$ (brs, $1 \mathrm{H}), 1.68$ (p, $J=$ $6.43 \mathrm{~Hz}, 2 \mathrm{H}), 2.24-2.37$ (m, $4 \mathrm{H}), 2.48-2.53(\mathrm{~m}, 2 \mathrm{H}), 3.41$ (s, 3 H), 3.62-3.64 (m, 2 H), 3.86-3.94 (m, 2 H), $4.28(\mathrm{~m}, 1 \mathrm{H}), 4.59$ (s, $2 \mathrm{H}), 4.77(\mathrm{~s}, 2 \mathrm{H}), 7.30-7.37(\mathrm{~m}, 5 \mathrm{H}) .{ }^{13} \mathrm{C}$ NMR $(100 \mathrm{MHz}$, $\left.\mathrm{CDCl}_{3}\right): \delta=-4.7,-4.4,17.9,22.2,25.8,27.9,55.5,67.1,71.2$, $71.6,73.4,74.8,78.6,80.9,85.8,95.9,127.6,127.6,128.4 \mathrm{~S}$, 138.2. HRMS: $m / z[\mathrm{M}+\mathrm{Na}]^{+}$calcd for $\mathrm{C}_{28} \mathrm{H}_{44} \mathrm{O}_{5} \mathrm{SiNa}$ : 511.7212; found: 511.7211 . 